\title{
Cultural Concord of the East and the West in Pearl Buck's Novels on China
}

\author{
Ling'e Shu \\ School of Foreign Languages \\ Jianghan University \\ Wuhan, China 430056
}

\begin{abstract}
Pearl Buck is the famous American writer in the 20th century. She lives in two worlds, the world of her American missionary parents and the world of a continually fascinating Orient, where lived more than 30 years. Pearl Buck has deep affection for China and the Chinese people and makes China as the subject matter in most of her writings. The thesis is endeavored to explore Buck's cultural concord of the East and the West embodied in her novels by analyzing some of her novels focusing on China and Chinese people, consisting of her genuine description of China and intercultural marriage between the East and the West.
\end{abstract}

Keywords-Pearl S. Buck; cultural concord; genuine portrayal; intercultural marriage

\section{INTRODUCTION}

Pearl Buck, whose full name was Pearl Sydenstricker Buck, was born in Hillsboro, West Virginia, on June 26, 1892. Her parents, Absalom and Caroline Sydenstricker, were Southern Presbyterian missionaries stationed in China. She was born when her parents were near the end of a furlough in the United States. But when she was only three months old she was brought to China by her parents in a market basket, where she lived more than 30 years. Since young, she liked to read both Chinese texts such as selections from Confucius, Mencius, and some of the major poets and English books such as Fox's Book of Martyrs, Plutarch's Lives, The Bible, the poems of Tennyson and Browning, the novels of Scott and Thackeray, and above all the works of Dickens. She lives in two worlds, the world of her American missionary parents and the world of a continually fascinating Orient. She has created about 70 works including East Wind: West Wind, The Good Earth, Dragon Seed, Pavilion of Women and so on. Pearl Buck has deep affection for China and the Chinese people and makes China as the subject matter in most of her writings, especially her concept of the concord of the East and the West. In1938 she was awarded the Nobel Prize in Literature "for her rich and truly epic descriptions of peasant life in China and for her biographical masterpieces." and in her speech to the Academy, she took as her topic "The Chinese Novel", which she explained "I am an American by birth and by ancestry, but my earliest knowledge of story, of how to tell and write stories, came to me in China." In the end she concluded that in China "the novelist did not have the task of creating art but of speaking to the people."
Therefore, for her novels on China, on one hand, Buck displays a genuine description of China. Chinese people are always described as fantastic, ridiculous, evil and ignorant, which fully shows Westerners' absolute and dogmatic discrimination against Chinese people. As a witness to the situation of the modern Chinese nation, Pearl Buck owns the firsthand information about China and thus has a unique vantage to present China as objectively as possible. Therefore, the Chinese culture and Chinese people in Buck's novels are so genuine, colorful and full of affection. On the other hand, Buck tends to promote the intercultural marriage between the East and the West. In Buck's novels, those people with different cultural background can marry, such as American man Alex with Chinese woman Louise in Kinfolk and also American woman Mary with Chinese man, Kweilan's elder brother in East Wind: West Wind.

\section{BUCK's GENUINE PORTRAYAL OF CHINA}

Everything is relative, cultural difference being no exception. Culture, as the total pattern of human behavior and its products, oversteps geographical limits and historical conditions in many ways, and it is characterized by its strong penetrativeness and fusibility. The pioneer of French comparative literature, Charles says, "Nothing is isolated and the true isolation means death. The actions and re-actions of all the nations are mutually influential and connected. Those who have no communication with others are only holes in a huge net." (Dong Guangjie, 1999 : 246) Generally, culture is pluralistic, dynamic, open, communicating, blending and sometimes is in conflict.

Cultural concord of the East and the West is embodied in many of Pearl Buck's novels, but the most important is her genuine portrayal of China. Chinese people are always described as fantastic, ridiculous, evil and ignorant, which fully shows Westerners' absolute and dogmatic discrimination against Chinese people. In sharp contrast with it, the Chinese culture and Chinese people in Buck's novels are so genuine, colorful and full of affection.

\section{A. Chinese Images in Former Westerners' View}

In the nineteenth century, American people knew almost nothing about China but only a handful of merchants, soldiers, and diplomats had set foot in China or in any other Asian country. While among those who did have an opinion 
about the Chinese, it seemed clear that hostility far outweighed approval. After the Boxer Uprising Chinese people were indeed described as murderous heathens. In the songs and jokes of popular culture, the wily and inscrutable Chinaman joined the drunken Irishman and the avaricious Jew as a stock comic figure. Newspaper cartoons, an innovation of the $1890 \mathrm{~s}$, quickly began pandering to the national Sinophobia. Daily and Sunday strips were filled with the slanted eyes, long queues, and robes of burlesque characters who muttered in Pidgin English as they schemed, soliloquized, and eventually came to some bad end or other.

American Chinatown became known as places of mystery, vice, gambling, filth and strange odors. Chinese images could be found in serious journals as well as the sensational press. A writer in The Galaxy, for example, proposed that "the Mongol and the Negro are but human saurians that reached long ago $\cdots$ their full development, and are now moral fossils."(Quoted in Eiseley, 1961:264) Unfortunately, the same poisonous attitudes were expressed by the men who managed America's foreign affairs at the turn of the century. Theodore Roosevelt described the Chinese as an "immoral, degraded and worthless race" (Conn, 1996:32). Roosevelt's first Secretary of State, John Hay, always referred to the Chinese as "chinks."

Western customs and practices, no matter how arbitrary, were taken to be the human norm. A classical statement of the case first appeared in a famous cartoon "Believe It or Not!" by Robert Ripley, in May, 1932. It amused the readers with the revelations that Chinese coins have holes in them and that the Chinese character for "peace" is a pig under a roof. The question "Can a Chinaman Whistle?" filled one box; another box, under the label "The Heathen Chinese Is Peculiar," offered the apparently shocking news that Chinese use the color white to signify mourning, that the Chinese calculate age and write fractions differently, and that Chinese men remove their shoes instead of their hats when entering a house.

For so long a time Chinese people have been always described as ridiculous, evil, queer and inconceivable by the Westerners, thus they look down upon the Chinese people and are even unwilling to keep in contact with them.

\section{B. Chinese Images in Buck's View}

Pearl Buck is simultaneously an outsider and an insider in two different worlds. Just as she says,

"I grow up in a bicultural world - one is my parents' missionary world, a small white clean American world; the other is the big lovely not-too-clean Chinese world - but there is a wall between them. When I am in the Chinese world I am Chinese, I speak Chinese, and behave as a Chinese and eat as the Chinese do, and I share their thoughts and feelings. When I am in the American world, I shut the door between." (Buck, 1991:9)

She is never quite sure where she belongs, or whether she belongs anywhere. The special living background has contributed her to the improvement of the communication of the East and the West.
Nearly all the Western people cannot get rid of the deeprooted prejudice against China and the Chinese people for a long time. However, Pearl Buck has tried to be the significant spokeswoman for China in American literature in the years from 1931 to 1972 . She is extremely unsatisfied with these people and will never adopt their standards which she regards to be absolute and dogmatic in judging about the Chinese people. We have mentioned above that stereotypes will hamper our intercultural communication. So a major goal of Buck's writings throughout her long career is to make Asia, especially China be displayed as genuine as themselves in front of the Westerners.

In her childhood, the Chinese amah often tells her the customs, the famine and the bandits in the countryside. She spends hours wandering Chinkiang's streets with her amah, overhearing the talk of ordinary people. She watches New Year's festivals and wedding and funerals, and learns that red is the color of good luck, white the color of death and mourning. Especially after she marries John Lossing Buck, an American agricultural specialist, she has a further knowledge of the folklore of the Orient. During their settlement in Anhui Province, she has made close contact with the local peasants and personally realized their diligence, wisdom and kindness. What's more, she is caught up in the Boxer Uprising of 1900, the 1911 Revolution, and the civil wars of the 1920s and 1930s. Therefore, her accounts of the Chinese people are rooted in a more extensive acquaintance than almost any other Western writers before.

Let's take The Good Earth as an example. From the day of its publication to the present, The Good Earth has been one of the best-selling books of the 20th century. The popularity of The Good Earth, is mainly because of its Chinese subject matter that had been vividly presented by Buck: "Drawing on decades of experience and observation, Pearl filled The Good Earth with the sights and sounds of China's daily life: the landscape and houses of a small village, the tools of the working men and women, the clothes the people wear and the food they eat, the rituals of marriage and death."(Conn, 1996: 131) Beyond that, the novel is significant for its attempt to negotiate the profound differences of language and culture that separate East and West. (Ibid, 129) She has created a peasant image with the high qualities of diligence, persistence, simplicity and kindness. The novel battles against the derisive attitudes, exchanging in the stereotypes of earlier American representation of Asia for a more firmly grounded portrait. She replaces the "inscrutable Oriental" and the "heathen Chinese" with a hardworking, ordinary farming family.

Buck has done much to alter American attitudes toward China, encouraging a sense of solidarity between the two nations that would have important strategic implications over the next decade. Furthermore, The Good Earth is a pioneering exercise in multicultural efforts. People can learn to read the image-banks of others and they can and should look across the frontiers of race, language, gender and age without prejudice or illusion. (Hughes, 1993: 83)

Communication barriers are obstacles to effective communication. By understanding intercultural 
communication barriers, we can break them down and pave the way for mutual understanding and respect. Known as "the novelist of China", Pearl Buck has successfully removed the obstacle - stereotype, between the East and the West and thus has greatly promoted the exchange and development of the world.

\section{BUCK'S PREFERENCE FOR INTERCULTURAL MARRIAGE}

Intercultural communication is first used by the famous anthropologist, Edward T. Hall in his foundational book, The Silent Language, in 1959 and is simply defined as interpersonal communication between members of different cultures.

Culture distinguishes human beings from the other living things and the interaction of human beings is certain to lead to the intercultural communication. Because of people's nature of communication and worship of the other and also the characters of culture itself, intercultural communication is just an objective reality which is not changed with people's will. (Yu Longyu, 1989:18)

The Indian national leader, Mahatma Gandhi (1869-1948) notes that no culture can live if it attempts to be exclusive. It is believed that intercultural marriage is one of the embodiments of intercultural communication. Therefore, cultural exchange is inevitable to realize the concord of Eastern and Western culture. Intercultural marriage means marriage between two people from different linguistic, religious, or ethnic groups or nations. For Pearl Buck, she has the same deep feeling about China and America and she insists that people of different cultures can and have to coexist. Since long time, Pearl Buck has regarded intermarriage as one of the most effective ways to achieve the understanding and communication of heterogeneous cultures and also enrich mutual cultures.

\section{A. Intercultural Marriage Between American Man and Chinese Woman}

In Kinfolk, Dr. Liang and his family have lived in America for many years. His youngest daughter Louise, who was born in America, is absolutely American in her manner and preference, representing the feelings of the typical young. So she is completely dissimilar to her elders, James and Mary. She is eager to marry Phillip, an American boy. However, she is strongly disapproved of by all her family and at last she is forced by her father to return to China. But this action cannot make her dismiss the idea. She makes the acquaintance of Alex, an American soldier in China. They fall in love with each other soon but secretly. After breaking all the obstacles and criticism of her family, they marry at last. Surprisingly, Louis keeps many traditions of China and becomes an old-fashioned Chinese wife, thoroughly subordinate and docile toward her husband.

The satisfactory marriage symbolizes that the infiltration of Chinese culture into Western culture. Besides, before their marriage Alex had a boy with a humble Chinese girl, who died after giving birth to the baby. Louise brought the baby with her to America. Before they carry the baby to America,
Mary makes a lot of clothes for the baby completely according to the American style. She also makes a basket for the baby, which is of Chinese style with silks and satins. She has combined the Chinese culture and American culture on the baby. Later, Louise and Alex give birth to their own baby, Dorothy. The two children, a boy and a girl, have closely blended the two different cultures.

\section{B. Intercultural Marriage Between American Woman and Chinese Man}

When Pearl Buck was 25 years old, her parents were worried about her marriage. Her father introduced a handsome Chinese gentleman, who had ever been Buck's students before. Buck was also very pleased with his father's arrangement. However, the man's parents refused to accept a foreign daughter-in-law. (Liu Long, 1993: 23) The incident is impressed in Buck's mind.

In the second part of East Wind: West Wind, Buck has arranged the same suffering of a foreign woman. In the story we learn that Kwei-lan's elder brother has returned from his study in the United States and he brings an American girl named Mary. Out of true love, they have married in America despite of his childhood betrothal to the daughter of Li. Being influenced by American life, he decides to act according to the modern, independent and free method of marriage in spite of the violent opposition of his parents. (Buck, 1993:457) But his parents strongly refuse to accept his foreign wife and order the son to send Mary back to her own country so that he can perform his proper family duty to marry the daughter of the family of Li.

After being refused by his parents, Kwei-lan's brother repudiates his family and cuts himself off completely from his relatives and ancestors at last. He is just breaking away from the traditional Chinese customs and the old decaying system in China. Kwei-lan's mother's death also predicts the doom of the old regulations and backward customs.

Finally Kwei-lan's brother and Mary succeed in giving birth to a baby despite all the traditional obstruction. When Kwei-lan carries the baby child to Mary, she could not help saying, "see what thou hast done, my sister! Into this tiny knot hast thou tied two worlds!" (Buck, 1998: 524) So the baby is the bond between the East and the West and symbolizes the integration of the eastern and western cultures. Although their marriage is not so successful at first, it just expresses the strong decision and confidence of Pearl Buck in intermingling the East and the West.

Intercultural marriage requires its participants to look at the world in a different way, to alter the long-established patterns of behavior, to properly deal with the prejudices and other negative attitudes of the two different cultures, and to learn some new thins and languages. Thus, indeed, through intercultural marriage Chinese culture has absorbed many different cultures, and simultaneously it has been enriched by other cultures. At the same time, our culture has also gradually infiltrated into the social levels and finally into the moral and value systems of the western people. Therefore, no races or cultures are destroyed, but they have improved each other forward. 


\section{CONCLUSION}

By describing China and the East in her novels Buck has successfully broken down the old stereotype of China and the Chinese people on the mind of all the Western people. Furthermore, she has introduced Chinese culture to the whole world and bridged the Eastern and Western cultures. Besides, Buck is also a humanitarian, philanthropist and crusader for women's rights. Pearl S. Buck is indeed one of the earliest writers who are dedicated to the communication between the East and the West in early $20^{\text {th }}$ Century, so she deserves the praise by the American President Richard Nixon as "a human bridge between the civilizations of the East and the West". Nowadays, Pearl Buck's reflections can also serve as a cultural resource to be made use of and referred to because they will surely illuminate people in their speculation about the intercultural exchanges.

\section{REFERENCES}

[1] Dong Guangjie, Li Luliang. Charm and Magic: A Perspective of Chinese and Western Cultures [M]. Beijing: China Textile Press, 1999.

[2] Pearl Buck. My Several Worlds: A Personal Reord [M]. Hunan: Hunan Literature and Art Publishing House, 1991.

[3] Pearl Buck. East Wind: West Wind [M]. Guilin: Minjiang Publishing House, 1998.

[4] Loren Eiseley. Darvin's Century: Evolution and the Men Who Discovered It [M]. New York: Doubleday, 1961.

[5] Pearl Buck. Fighting Angle [M]. England: Chivers Press, 1993.

[6] Peter Conn. Pearl Buck: A Cultural Biography [M] . London: Cambridge University Press, 1996.

[7] Liu Long. Pearl S. Research [C]. Yunnan: Yunnan People's Publishing House, 1992.

[8] Robert Hughes. The Culture of Complaint: The Fraying of America [M]. New York: Oxford University Press, 1993.

[9] Yu Longyu: The Differences and Similarities between Chinese and Western Cultures [C]. Beijing: Sanlian Bookstore, 1989. 